\title{
A psiquiatria no Rio Grande do Sul nas décadas de 40/50: relato pessoal
}

\author{
Psychiatry in Rio Grande do Sul in the 40s and \\ 50s: personal report
}

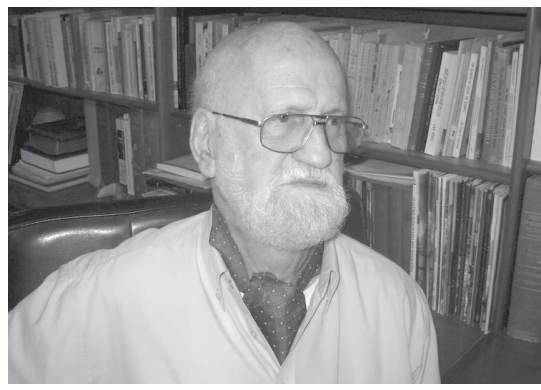

\author{
Sérgio Paulo Annes* \\ * Médico psiquiatra e psicanalista. E-mail: sergioannes@gmail.com
}

A convite dos editores da Revista de Psiquiatria do Rio Grande do Sul, relatarei um pouco de minha experiência de formação médica geral e, em especial, de formação na especialidade relativa à prática clínica e a internações psiquiátricas nos últimos anos da década de 40 e início dos anos 50. Sou da Turma Médica formada pela Universidade Federal do Rio Grande do Sul (UFRGS) no ano de 1947.

$\mathrm{Na}$ época não havia cursos para a formação de psiquiatras. Podíamos nos tornar psiquiatras com a ajuda de um professor que nos aceitasse como aprendiz. Tratava-se, como costumo chamar, de "uma formação artesanal", e não como hoje ocorre, em "uma linha de montagem", por assim dizer, em cursos com programas de ensino, vários mestres e anos de formação. Assim seguem hoje os cursos de formação de psiquiatras. O primeiro curso em nosso meio foi fundado pelos Drs. Paulo Guedes e David Zimmermann no ano de 1957, na Faculdade de Medicina da UFRGS.

Meu início na psiquiatria foi com o Prof. Celestino Moura Prunes, que, com suas aulas na disciplina de Medicina Legal, dadas no Instituto Médico Forense, encaminhava-nos para a psiquiatria. Ele foi, sem sombra de dúvida, o melhor professor que tive em minha formação médica psiquiátrica.

Manifestei o desejo de me dedicar à psiquiatria ao Prof. Dr. Décio Soares de Souza, que solicitou ao então diretor, Dr. Jacinto Godoy, permissão para que eu freqüentasse o Hospital Psiquiátrico São Pedro (HPSP). Fui levado pelo Professor à presença do Dr. Godoy, que de início se opôs, alegando que não queria pessoas estranhas freqüentando o HPSP. O Professor insistiu e terminou conseguindo a aquiescência do Dr. Godoy, procurando, no HPSP, pelo Dr. Victor de Brito Velho, para que com ele eu fosse aos poucos introduzido ao contato com os pacientes internados. Como o Dr. Brito Velho não foi encontrado, fui levado ao Dr. Mario Martins, que atendia na enfermaria de mulheres do HPSP. O Dr. Mário me recebeu muito bem, e assim marcou-se o início do meu trabalho na psiquiatria. Era-me permitido acompanhá-lo, e eu assistia a seus atendimentos a pacientes, e assim fui aumentando o contato com eles. Ele me aconselhava livros para ler, tais como: Semiologia (propedêutica psiquiátrica), do Prof. Nobre de Mello, o Manual de psiquiatria, do Prof. Dr. Mira y Lopes, a Propedêutica clínica psiquiátrica e o Tratado de psiquiatria, do Prof. Dr. A. Vallejo Nágera. Além disso, ele me estimulava a entrevistar pacientes, tomando notas em suas respectivas pastas.

O HPSP passou a ser e ainda deveria ser um hospital-escola, já que, na minha época, as aulas práticas de psiquiatria eram ministradas em suas dependências pelos Drs. Paulo Guedes e Ernesto La Porta. Os dois dividiam as turmas; a mim coube ter aulas práticas com o Prof. Paulo Guedes. As aulas teóricas eram ministradas pelo professor titular, Dr. Décio Soares de Souza, no anfiteatro da Santa Casa.

Os principais tratamentos hospitalares ministrados após a revisão clínica eram a eletroconvulsoterapia - a convulsoterapia com cardiazol já estava sendo abandonada -, a insulinoterapia (Sakel) com coma, estas duas associadas e a borrasca vascular induzida pela injeção de acetilcolina (que eu assisti no Hospital Espírita, aplicada pelo Dr. Pedro Rosa, embora nunca tenha aplicado). No tratamento da neurolues, antes da chegada da penicilina, na década de 40 , ainda era utilizada a malarioterapia associada a injeções de arsênico, bismuto e mercúrio. Os antipsicóticos químicos tiveram seu aparecimento entre nós nessa época. 
O Dr. Mário recentemente chegara de Buenos Aires, onde fizera sua formação psicanalítica com o Prof. Dr. Angel Garma. Posteriormente, chegaram a Porto Alegre os Drs. José Jaime Lemmertz, Cyro Martins e Celestino Prunes. Os dois primeiros, vindos de Buenos Aires, e o último, do Rio de Janeiro. Com esses quatro analistas, teve início o Núcleo de Formação de Psicoterapia de Porto Alegre, que posteriormente formaria a Sociedade Psicanalítica de Porto Alegre.

A enfermagem do HPSP era composta pelas freiras, irmãs de caridade da Ordem de Notre Dame. O HPSP estava sempre lotado, e as instalações eram precárias, a ponto de ser comum, nas enfermarias, que uma cama fosse utilizada para dois pacientes. Presenciei essa situação na enfermaria de mulheres.

Havia a promessa de um concurso para psiquiatra no HPSP, o que eu aguardava com interesse. Como tal concurso estava demorando, o Prof. Décio de Souza me levou ao Palácio do Governo para pleitear minha nomeação junto ao Governador Walter Jobim. Acabamos não sendo recebidos, e esta foi outra espera frustrada. Mais tarde, houve a nomeação de três psiquiatras, todos muito capazes. E o esperado concurso acabou por não acontecer.

Fui, então, para o interior do Estado, na cidade de Iraí, devido a problemas econômicos, já que não conseguira vaga no HPSP. Lá, por interferência do Prefeito, Israel Farrapo Machado, fui nomeado pediatra do Posto de Higiene.

O chefe político do local, Deputado Dr. Tarso Dutra, havia prometido ao Prefeito um pediatra para o Posto de Higiene, e eu fui indicado para ocupar o lugar. Mais tarde, consegui uma transferência para Porto Alegre, para o HPSP. Ainda como "extra numerário mensalista", permaneci até fazer um concurso para psiquiatra em uma autarquia federal. Fui aprovado e deixei o cargo estadual, pois na época não era permitido ocupar dois cargos públicos - "acúmulo de cargos". Não sei se esse critério ainda perdura.

No exercício da especialidade, eu atendia o Ambulatório pela manhã - situado no Edifício Santa Marta, em frente ao Edifício da Alfândega - e os pacientes internados em três hospitais: HPSP, Hospital Espírita e São José. Posteriormente, outros médicos foram incluídos nos quadros da autarquia, mas o critério era político, mediante indicação. A psiquiatria era considerada uma especialidade "simples" por colegas de outras especialidades. Trago uma lembrança pitoresca a respeito: certa vez, um colega pediatra, que trabalhava como psiquiatra na mesma instituição que eu, contou que, ao ser admitido na instituição, deram-lhe a possibilidade de escolher entre duas especialidades: ou trabalharia como oftalmologista, ou como psiquiatra. Optou pela psiquiatria, que, segundo ele, era "só conversa", pois se trabalhasse como oftalmologista seria um risco para os olhos dos pacientes.

Alguns anos após, além do acúmulo de pacientes e das dificuldades para manejá-los, também surgiu a possibilidade de eu me aposentar, a partir de uma lei criada pelo então Presidente Costa e Silva, que facultava a aposentadoria aos que tivessem 30 anos de serviço público na época da II Guerra Mundial e tivessem servido em zonas chamadas "de guerra", que, no Rio Grande do Sul, atingiam o litoral e a fronteira. Passei então a aposentado no Serviço da Autarquia, isto em 1968. Para contar os anos de trabalho, foram considerados o serviço militar, o concurso no Hospital de Pronto-Socorro, onde trabalhei durante o ano de 1947, e o tempo de interno, durante aproximadamente 3 anos, de 1945 até 1947, na enfermaria de cirurgia no Hospital da Brigada Militar, no Bairro Cristal. Neste, inicialmente eu auxiliava o Dr. Leone Scalco e, posteriormente, o Dr. Gilberto Netto Velho. Desde que me formei, mantenho consultório particular.

Em 1954, havia iniciado minha análise com o Dr. Mário Martins e, a partir de então, passei a trabalhar com psicoterapia de orientação analítica e psicanálise. A formação de analistas fora instituída com o reconhecimento da International Psychoanalytical Association, e o Grupo de Estudos Psicanalíticos que aqui formávamos foi reconhecido como Sociedade Psicanalítica de Porto Alegre no ano de 1963.

Venho trabalhando como psicanalista desde que concluí minha formação analítica, no ano de 1963. 